схемах підготовки, програмах навчальних дисциплін, інших нормативних документах, навчальній та навчально-методичній літературі.

Формою відображення змісту є навчальні предмети, інтегровані курси, які мають відповідати рівневі підготовки учнів і цілям їх вивчення [6, с. 49].

У початковій школі у більшості предметів провідним компонентом змісту $\epsilon$ застосування способів діяльності, тобто широкого кола різноманітних умінь і навичок. Однак, вони базуються на усвідомлених знаннях про те, чому і як їх треба виконувати. Наприклад, ознайомлення з довкіллям, етика і культура поведінки, валеологія переважно формують досвід емоційно-ціннісних ставлень і взаємозв'язків дитини: гуманні почуття, потреби, позитивний досвід спілкування i поведінки [3, c. 72], формування яких розпочинається в умовах дошкільного закладу.

Тому наступність у дошкільній i початковій освіті забезпечує вивчення таких навчальних дисциплін, як дитяча література, основи культури і техніки мовлення, методик викладання: математики, української мови, російської мови, іноземної мови.

Підготовка педагогічних кадрів дошкільної та початкової освіти щодо реалізації принципу наступності в умовах університету може забезпечуватись також шляхом поєднання спеціальності «Дошкільна освіта» і «Початкова освіта». Таке поєднання надає змогу підготувати педагогів, діяльність яких буде грунтуватись на компетентністному підході до формування особистості дитини, що в свою чергу передбачає не тільки когнітивний і операційно-технологічний складники, але й мотиваційну, етичну, соціальну, поведінкову сторони (результати освіти, знання, уміння, систему ціннісних орієнтацій).

\title{
Література
}

1. Вашуленко О. Питання наступності в педагогічній теорії / О. Вашуленко // Педагогіка і психологія. - 2005. - №4. - С. 49-58. 2. Енциклопедія освіти / В. Г. Кремень // Акад. пед. наук України; головний ред. В. Г. Кремень - К. : Юрінком Інтер, 2008. - С. 10-40. 3. Зязюн І. А. Філософія неперервної освіти: Здобутки, пошуки, проблеми / I. А. Зязюн // Матеріали Міжнародної науково-практичної конференції: у 6-и книгах, кн. 1. - Чернівці: Митець, 1996. 152 с. 4. Кузьмінський А. І. Організаційно-педагогічні основи безперервної освіти педагогічних кадрів: автореф. дис... канд. пед. наук / А. І. Кузьмінський - К., 1997. - 19 с. 5. Лубенец Н. Д. Общественные и семейные начала в детском возрасте / Наталия Дмитриевна Лубенец // Дошкольное воспитание. - 1911. - № 2. - С. 62-70. 6. Савченко О. Я. Дидактика початкової школи: підручник [для студентів педагогічних факультетів] / О. Я. Савченко - К. : Абрис, 1997. - 416 с.

УДК 37.035

Л. В. Кужільна, кандидат філол. наук, доцент, ДВНЗ «Криворізький національний університет»

\section{ІГРОВЕ ЕМОЦІЙНО-ДІЯЛЬНІСНЕ НАВЧАННЯ ЯК ПЕДАГОГІЧНА ТЕХНОЛОГІЯ}

Кужільна Л. В. Ігрове емоційно-діяльнісне навчання як педагогічна технологія.

У статті здійснено аналіз теоретичних основ методики М. Зайцева як педагогічної тенології, що задіює безліч сенсорних каналів, передбачає подання інформації блоками, підкреслює значимість опорних сигналів. Доведено, що розробки М. Зайцева дозволяють організувати розвивальний простір для дітей дошкільного і шкільного віку, надають педагогам змогу творчо підходити до готових програм, змісту освіти, способам його подання(методам і прийомам); вносити в роботу елементи дослідницької діяльності, кардинально скорочувати час оволодіння навиками читання i грамотного письма.

Ключові слова: складова теорії навчання, побуквене читання, розвиваючий простір, кубики.

Кужильна Л. В. Игровое эмоционально-деятельностное обучение как педагогическая технология.

В статье осуществлен анализ теоретических основ методики Н. Зайцева как педагогической технологии, которая задействует множество сенсорных каналов, предусматривает значимость опорных сигналов. Разработки Н. Зайцева позволяют организовать развивающее пространство для 
детей дошкольного и школьного возраста, дают педагогам возможность творчески подходить к готовым программам, содержанию образования, способам его подачи (методам и приемам); вносить в работу элементы исследовательской деятельности, кардинально сократить время овладения навыками чтения и грамотного письма.

Ключевые слова: составляющая теории обучения, побуквенное чтение, развивающее пространство, кубики.

Kuzhilna L. V. Game emotional activity training as educational technology.

This article analyses theoretical bases of methodology of teaching as Zaytseva technology that enables multiple sensory channels, provides a flow of information blocks, emphasizes the importance of strong signals. The development of $\mathrm{m}$. Zaitseva to organize a fast-paced space for children of pre-school and school age to give teachers the opportunity to creatively approach the finished programs, educational content, methods of its application (techniques and tricks); make the work items in the research activity, drastically reduce time to mastering the skills of reading and writing professional.

Key words: theory of learning on the part of the letter read, fast-paced space, cubes.

Підготовка дітей дошкільного віку до школи, за словами А. Богуш, «охоплює оволодіння практичними мовленнєвими навичками, удосконалення комунікативних форм і функцій мовної дійсності формування їі усвідомлення, яке може бути назване «лінгвістичним розвитком дитини». Оволодіння такими якостями ще в дошкільному закладі означає оволодіння умінням учитись. А це передусім уміння слухати, розуміти вказівки i пояснення дорослого; керуватись у своїй діяльності словесними вказівками; розуміння сенсу навчальних завдань, їх відмінностей від практичних; усвідомлення способів виконання дій; точне й ретельне виконання завдань відповідно до вимог; уміння працювати у певному темпі» [1, с. 705].

Свого часу, продовжуючи традицію К. Ушинського, Д. Ельконін розпочав розроблення методики початкового читання, виходячи 3 двох провідних принципів: 1) навчання читання має бути побудоване так, щоб воно було першим етапом тривалого і складного процесу оволодіння мовою; 2) оскільки навчання читання є навчання процесу відтворення звукової форми слова, то його слід розпочинати з уведення дитини до звуковоїу дійсності мови. Формування в дітей дій на встановлення послідовності звуків у слові Д. Ельконін уважав новим етапом у навчанні читання. Наступним етапом є орієнтування за приголосним голосним - етап словозміни. Навчання на третьому, останньому, етапі відбувається так: діти продовжують працювати зі схемою звукового складу слова, виокремлюють приголосний звук, ознайомлюються 3 його буквеним позначенням i замінюють відповідну фішку у схемі звукового складу слова літерою.

Після того, як діти оволодівають відтворенням звукової форми складу з опертям на зовнішню предметну дію (самостійне «конструювання складів»), розпочинають роботу, яка передбачає читання складів і слів за таблицями і буквами [3, с. 673-674].

М. Зайцев пропонує: 1 етап - відмова від термінологіi; 2 етап - перехід до знакових позначень граматичних категорій; 3 етап - оформлення складової теорії навчання читання.

Теоретичні напрацювання складового, а не фонемного принципу навчання оцінюються фахівцями як відкриття, аналіз якого і зумовлює актуальність нашого дослідження. «На жаль, в Україні цей метод не набув широкого розповсюдження. Хоча деякі дитячі садки мають посібники для навчання за М. Зайцевим» [2, с. 19]. Водночас, неправильне використання будь-якої технології чи методики не забезпечить досягнення бажаних результатів.

Дослідники методики М.Зайцева, зокрема Є. Шаріпова, зазначає, що треба відкинути попередні знання і змінити ідеологію навчання. О. Афанасьєва створила ігротеку Зайцева, яка дозволяє досягати досить вагомих результатів під час навчання читання.

Mema cmammi - викласти основні теоретичні основи пропонованої методики М. Зайцева; здійснити аналіз педагогічної і філософської літератури з розглядуваної проблеми; розкрити переваги й особливості методу М. Зайцева. 
Методика М. Зайцева передбачає дотримання таких принципів, які у традиційних методиках проголошуються, але не виконуються:

1. Від загального до окремого і від окремого до загального. В офіційній педагогіці головує принцип від окремого до загального.

2. Від конкретно-образного через наглядно-дієве до словесно-логічного. Дуже часто навпаки.

3. Наочність з використанням різних каналів сприйняття.

4. Системне подання матеріалу.

5. Алгоритмізація навчальних дій.

6. Облік фізіології сприйняття навчальної інформації й охорона здоров'я.

М. Зайцев розглядає гру як створення і підтримку організованої педагогом ситуації творчого пошуку одномоментної задачі, що може бути надзадачею для конкретної дитини, але цілком можлива і захоплююча для групи дітей. У процесі такої гри розв'язуються проблеми спілкування, творчості і, відповідно, виховання, навчання і здоров'я.

Діти четвертого року життя оволодівають навиками читання і письма через 6-7 місяців. Діти шостого-сьомого року життя через півтора-два місяці за умови двох - трьох занять на тиждень.

Побічні результати: зняття міопічних синдромів; уникнення насильницької послідовності реалізації програми; вся ігротека спрямована на формування колективу.

Переваги «інструментовки» М. Зайцева:

- усі завдання подано в найбільш повному обсязі, що виключає зайву інформацію;

- посібники надають змогу не відмовлятися від прийнятих методик, а використовувати їх як доповнення;

- навчальні матеріали діють на органи чуттів.

Аксіоми організації навчального простору:

1. Весь інструментарій дається в руки відразу, з першого дня. Ігри будуть служити відправними віхами в розвитку самого середовища.

2. Ніякого опертя на конструювання пам'яті чи уваги.

3. Виключити із вжитку слова «ні», «неправильно».

4. Ураховувати психофізичні особливості дітей цього віку.

Ігротеку «Кубиків» умовно поділено на 3 етапи: 1 - передбачає досягнення розкутості і зняття страху перед оволодінням новою справою - читанням, ознайомленням 3 конкретним розвивальним середовищем, формуванням готовності діяти в ньому; 2 передбачає спостереження за процесом розвитку сенсорики, закріпленню навичок читання і письма, подальшому розвитку навчального простору. На 3 етапі відбувається робота над подальшим формуванням клімату спілкування і розвитку.

Не зважаючи на глибокі історичні коріння проблеми розвитку, іiї сучасний стан пов'язується з іменами Л. Виготського і Ж. Піаже. Так, Л. Виготський уважав, що коріння проблеми треба шукати поза особистістю дитини; Ж. Піаже - що розумовий розвиток не залежить від навчання.

Позиції Л. Виготського розробили Д. Ельконін, В. Давидов, Л. Занков: без опори на чуттєвий світ навчання із засобу розвитку перетворюється на формальну, непотрібну самій дитині діяльність.

Якщо для школи Л.Занкова характерне твердження, що формування понять, які забезпечують розвиток мислення, відбувається поступово, у процесі розвивального навчання, то для школи Д. Ельконіна - організована пізнавальна діяльність дитини будується за іншою схемою:

- дитину з перших кроків ставлять в ситуацію набуття «узагальнених способів дій»;

- дитина має навчитися оперувати поняттями;

- усі завдання орієнтовані на запам'ятовування і відтворення.

Безумовно, розглядуваний процес не грунтується на емоційній основі. Крім того, розумовий розвиток неможливий без урахування ролі діяльності в розвитку мови. 
Розумовий розвиток, за Л. Занковим, може здійснюватися тільки в тих випадках, коли з боку тих, хто навчає, спеціально виявляється занепокоєння активним включенням свідомості в пізнавальну діяльність, коли не стільки отримання знань, скільки включення інтелекту в отримання відповіді стає основною метою навчання.

Самі ці особливості методики М. Зайцева не пояснені і до кінця не усвідомлені іiі автором.

Перетворення процесу навчання читанню із засобу на мету не тільки звільнило його від турбот про розвиток, але і об'єктивно зіткнуло його з тими, для кого найголовнішим було досягти усвідомлення ставлення дитини до предмета вивчення.

Яким би не був рівень розвитку свідомості у конкретної дитини, якщо іï достатньо для участі в грі, значить достатньо і для оволодіння будь-якою справою, будь-якими навичками, що пропонуються дитині в ігровій формі.

Навчання, яке будується на основі природовідповідності, забезпечує досягнення найвищих результатів, які не можливо досягти ніякою надприродною інтенсифікацією.

Сутнісна характеристика методу М. Зайцева полягає в тому, що він:

- значно скорочує термін навчання читання. За 3-4 заняття діти старшого віку починають читати, а через $2-25$ занять вони вже читають вільно, навіть не розуміють, коли навчились читати;

- забезпечує досягнення 100\% грамотності на письмі в подальшому навчанні;

- зберігає здоров'я дітей;

- має значний логопедичний вплив, ефективно впливає на розумовий розвиток.

Одна 3 головних особливостей методики М.Зайцева полягає в тому, що вона формалізована (на відміну від методик В. Шаталова і С. Лисенкової) i може бути застосована для широкого загалу, чого не скажеш про інші згадані методики.

Розглядувана методика певною мірою нівелює модель школи, де основним аспектом освіти є зміст інформації, яку треба передати учням, зосередженість на запам'ятовуванні, коли продукцією є факти, які запам'ятали учні. Освітні заклади, у яких навчальний процес здійснюється за такою моделлю, не здатні підготувати дитину до життя у XXI столітті.

1. Богуш А. М. Мовна підготовка дітей до школи / А. М. Богуш // Дошкільна лінгводидактика : хрестоматія : [навч. посіб. для студ. вищих пед. навч. закладів] / упоряд. А. М. Богуш . Ч.1 та 2. - К. : ВД «Слово», 2005. - С. 704-708. 2. Булдович М. Читати граючись. Кубики Зайцева. 3 досвіду роботи дитячого садка «Гармонія» / М. Булдович. - К. : Шкільний світ, 2009. - 128 с. - (Бібліотека «Шкільного світу»). 3. Журова Л. Є. Психологічні засади початкового навчання читання / Л. Є. Журова // Дошкільна лінгводидактика : хрестоматія : [навч. посіб. для студ. вищих пед. навч. закладів] / упоряд. А. М. Богуш. Ч.1 та 2. - К. : ВД «Слово», 2005. - С. 671673. 4. Турбовской Я. С. Игровое эмоциональоно-деятельностное обучение или теоретические основы методики Н.Зайцева / Я. С. Турбовской. - [Электронный ресурс]. - Режим доступа: http://www.metodikinz.ru/publ/?page=.sci.trubo\&dept=3.

УДК 366.632:378

І. Г. Максименко, кандидат пед. наук, доиент, О. Л. Пінська, кандидат пед. наук, доцент, Криворізький педагогічний інститут ДВНЗ «Криворізький начіональний університет»

\section{ПІДГОТОВКА МАЙБУТНІХ ПЕДАГОГІВ ДО КОМУНІКАТИВНОЇ ДІЯЛЬНОСТІ В НАВЧАЛЬНОМУ ПРОЦЕСІ ВИЩОЇ ШКОЛИ}

Максименко І. Г., Пінська О. Л. Підготовка майбутніх педагогів до комунікативної діяльності в навчальному процесі вищої школи.

У статті висвітлюється сутність комунікативної діяльності, розкривається технологія 